\title{
An Analysis of Effect Servicecape, Innovation and Consumer Dissatisfaction Towards The Consumer Attitudes at Internet Cafe Business in Medan Tembung District
}

\author{
Sunday Ade Sitorus \\ \{sundayadecoms@gmail.com\} \\ State Lecturer Kopertis 1 North Sumatera, Indonesia
}

\begin{abstract}
This research was aimed at revealing and analysing the effect of the Servicecape, and innovation towards consumer dissatisfaction and consumer attitudes to the internet cafe business. This research employed an accidental sampling method to collect data from 220 respondents. Data analysis methods employed SEM analysis to reveal the effect of the Servicecape, and innovation towards consumer attitudes and provide the effect on consumer dissatisfaction on the Internet cafe business. The Research Results showed that: 1). Servicecape had a negative effect yet significant towards consumer dissatisfaction to the Internet cafe business. 2). Innovation had a positive and significant effect toward sustainable competitive advantage to the Internet cafe business. $3)$. Servicecape had a positive effect yet significant towards the consumer attitudes to the internet cafe business. 4). Innovation had a positive and significant effect towards the consumer attitudes to the internet cafe business. 5). Consumer Dissatisfaction had a positive and significant effect towards the consumer attitudes to the Internet cafe business. In this case, according to the results of SEM analysis, it could be noticed that the Servicecape had non-significant effect towards the consumer dissatisfaction; however, innovation may sustainably enhance the consumer attitudes. Therefore, the internet cafe business owner, in order to be able keeping their business to survive, they must create innovation against internet services product as well as some of the technical dimension embodied in the consumer attitudes.
\end{abstract}

Keywords: Servicecape, Innovation, Consumer Attitudes and Consumer Dissatisfaction.

\section{Introduction}

During the current global conditions, the flow of information is very and its influence can be quickly seen and felt in the community. Global culture has changed the local world very quickly and intensively. Modern lifestyles are becoming a popular culture today and the culture of leisure in the Internet Cafe has become a habit in the community which is unwittingly an influence of globalization. Internet Cafe has become a lifestyle of adolescents today. After class, between school hours, even after office hours, teenagers and young people tend to spend their time playing at the Internet Cafe. If the location of a strategic Internet Cafe, affordable prices, a comfortable place, and internet speed become a favourite gathering place for young people. One of the ways undertaken by these businesses is to improve the physical 
environment (servicescape) to meet customer satisfaction. Servicescape or physical environment is a physical facility of an organization that is used to influence consumers' feelings to be happy and positive (Pangkey, 2013). The attractive physical environment of the Internet Cafe has indeed become one of the main attractions for consumers to visit the Internet Cafe. Through the servicescape of Internet Cafe business people can provide good quality services for consumers to feel comfortable while in the Internet Cafe. It is undeniable that with this good management of servicescape, it will provide added value to an Internet Cafe in order to create a loyalty from consumers. The physical environment (servicescape) is defined as the regulation of physical facilities in the services that occur and which influences consumers' perceptions of quality and subsequent internal (ie satisfaction level) and external (ie behavior in relation to purchasing) responses (McDonnell and Hall 2008). The dimensions of the servicescape contained in the Internet Cafe include the following, providing good lighting so that consumers can see well around the room, there is air ventilation so that the room temperature remains cool, the colour dominance is designed according to the Internet Cafe theme, the environment outside or inside the room Internet Cafe is clean, music that supports a relaxed atmosphere, room layout and equipment are arranged neatly so as not to disturb visitors, the tools used by the Internet Cafe are clean and functioning as they should, signs or instructions that are installed make it easy for visitors to reach the facilities provided by Internet Cafe. Waiters and consumers dress neatly when visiting the Internet Cafe. The development of the internet causes the formation of a new arena that is often called the virtual world. Each individual has the right and for related to another individual without any restrictions that prevent the Globalization basically has been implemented in the virtual world which has been connecting the entire digital society or those who often use the internet in the activity of his life every day. With a population of 250 million, Indonesia is a potential market and will be the biggest one in Southeast Asia in the case of internet usage. According to research MarkPlus Insight the population of Indonesia that have access to the internet on 2010 reach $35 \%$ and 2016 has reached $55 \%$, so there are still $45 \%$ again that do not already have them spread in the island so that the blank spot him is still very large (tekno.kompas.com). This causes can bring new business in using the internet and eventually appear entrepreneurs who build new internet cafes. Based on the survey of Tourist Entrepreneurs Cyber (APW), the development of the number of internet cafe on 2011 is already penetrate 20,000 business unit (www.bataviase.co.id) and this makes the competition in internet cafe business is increasingly tight and potentially dig very potential market share to sustain life. The development of the Internet Cafe in Indonesia is not a new thing in the world of business, due to business on the internet cafe very can provide huge profits for the entrepreneur's form. The management of the internet cafe business does not remove from the aspects of marketing, operational technical, financial and human resources and the management of Internet cafe also does not remove from the innovation, due to innovation aims to maintain the survival of the business, because the product that is vulnerable to changing needs and consumer taste, technology product life cycle a shorter, as well as increasing competition among internet cafe business players. Changes that occurs in the internet cafe business environment has forced the internet cafe business managers to be able to create the thought and new ideas and offers innovative facilities in the form of computer technology is a sophisticated design and space layout play internet and comfortable facilities, online gaming and so on. Thus, the innovations increasingly have significance not only as a tool for the survival of the company but also for the competition. According to Lumpkin and Dess (Marques \& Ferreira, 2009) that innovation reflects the tendency of companies to provide support to new ideas, novelty, effort and the creative process that can produce new products and services or the process of technology. 
Sulistiani (Sulistiani, 2014) explains that sustainable innovation in a company is the basic needs which in turn will lead to the creation of competitive advantages. Due to the market, internet cafe very wide and a very tight competition. Each businessman or internet cafe managers must be able to win the market by creating a new innovation and provide a brilliant idea for the continuation of the business. Innovation can also be used as one of the strategies to achieve the competitive advantage. Customers generally want innovative internet stalls in accordance with their desire. For the managers of internet cafe, its success in doing innovation means the internet cafe business step more developed than their competitors (Boons, Montalvo, Quist, \& Wagner, 2013) revealed that the innovation process is considered the fundamental driving forces to bring about the transition in society toward sustainability and innovation also contributes to the challenges of sustainability transitions, because the innovation process lead to the development of new technology and practice that is required to effectively achieve sustainable business. The importance of innovation done against the internet cafe business due can provide benefits that can accelerate business growth, change from small businesses to large, able to create the diversification by doing business multiplication, can control of the market and the competition as well as the control of various changes that continue to occur (Ehmke, 2008). According to Drucker (Drucker: \& Customers,2002), innovation is a special tool businessman, means that exploit the changes as an opportunity for a different business or a different service. This can be served as a discipline in implementing new ideas and able to learn toward a better and practiced in accordance with the requirements. The perpetrators of internet cafe business need to find the source of innovation and apply the principles of successful innovation. Assessment of innovation can be done through the indicator related to each other on the creation of innovation, namely: Creativity power, technical changes, design changes, distribution system changes, and administration system (Sulistiani, 2014). From this, the competition in the internet cafe business can be circumvented through the innovation and a business player of internet cafe is able to make a distinction between the perpetrators of other business.

The competition among the entrepreneurs of internet cafe in captured the customer does not remove through the quality of service. The quality of services serving as a means where the management of the company or inform, persuade and remind consumers directly or indirectly about the products or services that will be sold (Armstrong, Kotler, Harker, \& Brennan, 2009) The quality of service that has done the managers of internet cafe will create a separate assessment on the thinking of the customer, so that the assessment of consumers of services either directly or indirectly, will create the image of the internet cafe services. When the perpetrators of the internet cafe business view consumer dissatisfaction then must be prepared the criteria to survive in the market which have the uniqueness of the internet cafe facilities, very difficult to imitate the pattern of service to the customers, creating innovation in the competition, creating sustainable internet connection, able to face many situations in the market (Boons et al., 2013)). To maintain the competitive advantage, then every business player must act in a way that makes it difficult to excellence in transactional replication or Imitated by competitors. Based on data from the Communication and Informatics Department of Medan, until 2016 been counted already exists 828 internet cafes which had stood and who have not been counted almost reached the number 2000 internet cafes spread in 21 subdistricts in the City of Medan. The current mushrooming internet shops in the city of Medan, not many experiences changes the network connection internet owned has not been able to satisfy customers and some aspects of the activities of the technical, up to the lack of innovation in creating something new in internet cafe, quality services to the competitive advantage is not running with the good and right. This makes many customers internet cafe 
switch to the other means of hand phone, personal notebook with search for free (free wifi and other facilities. Especially in the sub-district Medan Tembung, many internet cafe business establishments, but not included with various services and facilities that bad. As shown in the table below, based on the pre survey done, the development of the number of internet cafe that stand and the lid on the year 2017 - 2019 Districts Medan Tembung, as follows:

Table 1: The development of the number of Internet Cafe for period of 2016 - 2018

\begin{tabular}{|l|l|l|l|l|l|l|}
\hline \multirow{2}{*}{ Village } & \multicolumn{3}{|c|}{ Internet Cafes That Survive } & \multicolumn{3}{l|}{ Internet Cafes That Close } \\
\cline { 2 - 7 } & 2017 & 2018 & 2019 & 2017 & 2018 & 2019 \\
\hline Indra Kasih & 15 & 20 & 40 & 6 & 7 & 5 \\
\hline Sidorejo & 20 & 35 & 65 & 3 & 5 & 9 \\
\hline Sidorejo Hilir & 35 & 45 & 55 & 5 & 6 & 10 \\
\hline Bandar Selamat & 20 & 34 & 45 & 5 & 7 & 12 \\
\hline Bantan & 23 & 35 & 40 & 6 & 4 & 10 \\
\hline Bantan Timur & 21 & 33 & 50 & 5 & 8 & 15 \\
\hline Tembung & 21 & 35 & 76 & 6 & 12 & 11 \\
\hline
\end{tabular}

Source: Pre- Field Surveys, Processed Data

Based on the above Table, the growth of internet cafe business is increased since it offers a great deal of profit. However, this business is highly correlated with bankruptcy. In line with the Table above, the bankruptcy of such business experiences a significant annual increase and a huge amount of loss. If this remains occur, it may result in negative effect towards the sustainability of the other internet cafe business. In other words, unlike the destiny of telecommunication café, we should put our big effort to maintain internet cafe business. Therefore, activities related to such business must be coordinated and planned by business owners properly so that all of these activities may result in the expected purpose as planned by the owners. In order to maintain the development of the business, especially in fulfilling consumer's need, the analysis on the effect of service and innovation towards Consumer's Attitude and Dissatisfaction towards internet cafe business is significantly required.

\section{Literature Review}

\subsection{Innovation}

Innovation refers to brand new creations (both tangible and intangible) that have meaningful economic value (significant), that such activities are generally performed by companies or, sometimes, individual. According to (Rogers, 2008), innovation means idea, notion, practice or object/thing, that are realized and accepted as a new thing by any individual or group to be adopted. According (Robbins, 2013) innovation is a new construct applied to initiate or improve a product or process and service. Based on the above definitions, Robbins is more focus in three major matters in performing innovation, they are: new construct, which means a pattern of thinking in observing an occurring phenomenon, including in the field of education, this new construct may be in the form of discovery in a notion, idea, system, to the crystalized probabilities. Product or service refers to the outcome of further step new notion followed by activity, study, research and trial so that they may result in more concrete concept 
in the form of product and service that are ready to be developed and implemented including the outcome of innovation in the field of education. The effort in improvement refers to systematic effort to establish constant perfection and improvement so people may use it. [9] states that innovation is development and implementation of new notions by any individual, in which in particular period of time, has performed transactions with other people in a board of organization. According to [10], innovation is not one time phenomenon, it otherwise in a long and cumulative process that includes many processes of decision making in and by organization that started from the discovery of notion up to its implementation in the market. Based on Law Number 18 of 2002, innovation is an activity of research, development and/or engineering that aims to develop the practical implementation of value and context of new knowledge, or new mean to implement the existing knowledge and technology into the product or production process. [11], contend that innovation is an ability to adopt creative solution towards any problem as well as opportunity to increase or enrich someone's life. [12] affirms that innovation is a unique strategy of product development produced by competitor. If a company uses innovation strategy, the necessary attitude are:

a. Degree of creativity

b. Long-term focus

c. Degree of cooperation

d. Interdependent attitude

e. Sufficient concern towards quality and quantity

f. Balance between outcome and process

g. Accept the risk and tolerate uncertainty.

\subsection{Servicecape}

Lovelock, Wirtz and Mussry (2010), defines servicescape as the style and appearance of physical and other elements of experience encountered by customers at the delivery service. The same opinion was expressed by Bitner (Mursiha, 2009), arguing that servicescape is a physical environment or physical facilities where these services are produced, delivered, and consumed. Through some understanding from previous researchers, it can be concluded that servicescape is the physical environment and other elements that are influenced by behavior while using certain services. According to Bilbao and other organizations in Lovelock, Wirtz and Mussry (2010), there are 4 main objectives of servicescape, namely: Forming experiences of consumer behavior, as imaging, positioning, and differentiation, Being part of a value proposition, Facilitating delivery of services, and strengthening at the same time service productivity. Servicescape is equated with landscape including exterior facilities (landscape, exterior, design, signs, parking, environment) and interior facilities (interior design and decoration, equipment, signs, layout, air quality, temperature and atmosphere). Servicescape and other physical evidence such as business cards, stationery, billing statements, reports, employee clothing, uniforms, browsers, web pages and forms of physical evidence servicescape virtual may play a significant role in marketing services

\subsection{Consumer's Dissatisfaction}

Consumer's dissatisfaction is one of factors that may lead the customer to move to another brand. As conveyed by [15], a consumer experiencing dissatisfaction has the probability to alter his attitude of buying decision by finding alternative brand in his next consumption to increase his satisfaction. If manufacturers exaggerates the advantage of a product and the degree of expectation or consumer's satisfaction is not accomplished, it will 
lead to consumer's dissatisfaction [16] Meanwhile, according to [17], consumer's satisfaction basically includes the difference between expectation and performance or the expected outcome. Assessment towards consumer's satisfaction may be categorized into: a) Positive disconfirmation, in which the received outcome is better that the expectation., b) Simple conformation, in which the received outcome is in line with the expected outcome. In the end, consumer who is satisfied upon his need and desire will perform further step by buying similar brand anymore. On the contrary, dissatisfied consumer is more likely to change his buying attitude by moving to the other brand. One of factors that arises in a consumer's self that may cause him to have the desire to move to the other brand is the consumer's dissatisfaction towards a product, so he will move to the other brand [18]. The consumer's dissatisfaction may result in his disappointed attitude and even more anger to such product and has further consideration to decide or leave such product [19].

\subsection{Consumer's Attitude}

Attitude refers to evaluation, someone's feeling, and the tendency of action that may provide profit or loss and remains in a long time in someone towards the particular object or notion [16] The other definition for attitude is evaluation, feeling and relatively consistent tendency by someone towards any object or idea [6]. According to [20], attitude refers to the core of the feeling of like and dislike towards people, group of people, situation, object and particular abstract idea. Attitude of difficult to change. Someone's attitude forms a pattern, and to change it, complicated adjustment in many things is needed. Thus, company must always put its effort to adjust its product with the existing attitude other than to try to change attitude [6]. Mostly, consumer buy any product without developing his previous feeling or affection [20]. Consumer will firstly establish his trust towards any product that is directly followed by product purchase. But, he will start to create his feeling towards such product after the purchase completed.

\section{Methodology}

This research is conducted by using survey method as the approach. While the type of this research is descriptive and quantitative, which means that it aims to outline or describe the characteristic of a condition or research object that is quantitatively conducted through data collection and analysis as well as statistical test [21]. This research is explanatory, which aims to explain the position of tested variables and the relationship among variables [22] This research is conducted in the Region of Medan Tembung District, Medan City, which contains 7 Sub-Districts.

\subsection{Population and Sample}

Population used in this research are all internet café owners in Medan Tembung District. Until 2019, there are 371 business. The technique applied to collect the sample in this research by by Quota Sampling, which means the technique of sampling where the researcher previously decides the number of desired subjects in the research (Idrus:2009). Related to the number of sample, according to Hoogland and Boomsma (Ferdinand:2002), upon sampling in SEM research, the number of indicators should be multiplied by five to 10 and the data with 
high kurtosis, the minimum sample size must be 10 times than the number of free parameter.

The indicator in research is amounted to 22 .

Number of Samples $=$ Indicator $\mathrm{x} 10$

$$
\begin{aligned}
& =22 \times 10 \\
& =220
\end{aligned}
$$

Based on the above calculation, the Number of samples in this research are 220.

\subsection{Data Analysis Method}

The first stage before data collection was goodness-of-fit test, which covered the realiability and validity, or evaluation of the questionnaire that had to be carried out.

a. Validity

b. Reliability

The second stage was making a model to be used in this research, which was causality model or relationship or effect model. To test the proposed hypothesis, an analysis was conducted using SEM (Structural Equation Modelling) technique and Software AMOS 18.0 .

c. Theoretical model Development

d. Path diagram Development

e. Input matrix selection and model estimation

f. Analysis of the possibility of identification problem

g. Evaluation of goodness-of-fit criteria

In this stage, an evaluation of the fitness of the model was carried out by reviewing the Goodness-of-fit criteria in the following order:

1. SEM Assumption

The first action was evaluating whether the data used met the SEM assumptions, namely: sample size, normality and linearity, outliers, multicollinearity and singularity.

2. Goodness-of-fit test \& statistical Test

Some indices of goodness-of-fit and cut-off for testing whether the model should be accepted or rejected are as follows:
a. Chi-square stastitic
b. Probability
c. Goodness-of-fit index (GFI)
d. Adjusted Goodness of-fit Index (AGFI)
e. Comparative Fit Index (CFI)
f. Tucker Lewis Index (TLI)
g. The Root Mean Square Error of Approximation (RMSEA)
h. Model interpretation and modification
i. Modification Index. 


\section{Result and Discussion}

\subsection{Structural Equation Modeling Statistical Analysis}

Exogenous and Endogenous Construct Confirmatory Factor Analysis and . Structural Equation Modeling Analysis the full model picture should be supported by the results of the regression weight as presented below.

Table 2, Model Feasibility Test Results

\begin{tabular}{llcl}
\hline Goodness of-Fit Index & Cut-off Value & Results & Model \\
\hline Chi-Square & $<575.208$ & 76.8 & Good \\
GFI & $>0.90$ & 0.974 & Good \\
TLI & $>0.95$ & 0.989 & Good \\
CFI & $>0.95$ & 0.998 & Good \\
CMIN/DF & $<2.00$ & 1.423 & Good \\
RMSEA & $<0.084$ & 0.035 & Good \\
\hline
\end{tabular}

The table of research results show that in the full model testing, the model has been categorized into good or has met the goodness-of-fit criteria. It is based on all criteria already fulfilled with the feasibility test of the model based on the Cut off Value provision. The GFI value of 0.974 was categorized into good, and was higher than the cut-off value, which was 0.90 . The good category of GFI criteria with the value of 0.974 was higher than the Cut-off value of 0.90 . The result of chi-square test towards the full model was 76.8 , lower than the chi-square for the degree of freedom (DF) of 320 in the significant level of $5 \%$ amounted to 575.208. The CMIN/DF was 1.423, lower than the cut-off value amounted to 2.00. The TLI value was 0.989 , higher than the cut-off values of 0.95 . The CFI value was 0.992 , higher than the cut-off values of 0.95 , and the RMSEA was 0.035 with the cut-off values lower than 0.084. The research results showed that the full model complied the fit model criteria, and it complied the model's feasibility to answer research hypothesis. The observed criteria (indicator) of each variable was valid if it has loading value more than 0.5 , so that there was no indicator dropped (discarded). Each indicator of latent variable formers shows result complied with the criteria: $\mathrm{CR}$ value was more than 1.56 with $\mathrm{P}$ was lower than 0.05 and the lambda value or loading factor was higher than 0.5 . The research results showed that the indicator of latent variable formers was significantly the indicator of formed laten factors. Thus, the model used in this research can be accepted.

\subsection{Regression Weight Analysis}

\subsubsection{The effect of Servicecape towards Consumer Dissatisfaction to the Internet Cafe}

Hypothesis Test Results with interpretation of each path coefficient or direction of causal correlation, the obtained hypothesis test results are as follows: Servicecape (X1) was significantly affecting the Consumer Dissatisfaction (Y1) with a positive direction of correlation. It showed from the positive-marked-path coefficient (S.E) amounted to 0.84 with the $\mathrm{CR}$ value of -1.010 and the significance probability $(\mathrm{p})$ was 0.044 lower than the determined significance level $(\alpha)$ of 0.05 . According to the research results, it showed that the Servicecape had a negative effect yet significant towards Consumer Dissatisfaction to the internet cafe.. 


\subsubsection{The effect of Innovation towards Consumer Attitudes to the Internet Cafe}

Interpretation of each path coefficient or direction of causal correlation, the obtained hypothesis test results are as follows: Innovation (X2) had an insignificant effect on Consumer Attitudes (Y1) with a positive direction of correlation The positive-marked-path coefficient (S.E) amounted to 0.67 with the $C R$ value of 16.375 and the significance probability (p) was 0.000 lower than the determined significance level $(\alpha)$ of 0.05

\subsubsection{The effect of Servicecape towards Consumer Attitudes to the Internet Cafe}

Hypothesis Test Results with interpretation of each path coefficient or direction of causal correlation, the obtained hypothesis test results are as follows: Servicecape (X1) had an insignificant effect towards Consumer Attitudes (Y) with a positive direction of correlation. It showed from the positive-marked-path coefficient (S.E) amounted to 0.79 with the CR value of 1.729 and the significance probability (p) was 0.184 higher than the determined significance level $(\alpha)$ of 0.05

\subsubsection{The effect of Innovation towards Consumer Attitudes to the Internet Cafe}

Innovation was significantly affecting the Consumer Attitudes (Y) with a positive direction of correlation. The positive-marked-path coefficient (S.E) amounted to 0.422 with the CR value of 2.625 and the significance probability (p) was 0.005 lower than the determined significance level $(\alpha)$ of 0.05 ..

\subsubsection{The effect of Consumer Dissatisfaction towards Consumer Attitudes to the Internet Cafe \\ Hypothesis Test Results with interpretation of each path coefficient or direction of causal correlation, the obtained hypothesis test results are as follows: Consumer Dissatisfaction (Z) was significantly affecting the Consumer Attitudes (Y) with a positive direction of correlation. It showed from the positive-marked-path coefficient (S.E) amounted to 0.483 with the CR value of 2.746 and the significance probability (p) was 0.019 higher than the determined significance level $(\alpha)$ of 0.05}

\section{Conclusions}

According to the research results and discussion in the previous chapter, it can be concluded as follows:

a. Servicecape had a negative effect yet significant towards Consumer Attitudes to the internet cafe business.

b. Servicecape had a positive effect yet insignificant towards Consumer Dissatisfaction to the internet café

c. Innovation had a positive effect yet significant towards Consumer Attitudes to the internet cafe.

d. Innovation had a positive effect yet significant towards Consumer Dissatisfaction to the internet cafe.

e. Consumer Dissatisfaction had a positive effect yet significant towards Consumer Attitudes to the internet cafe 


\section{References}

[1] Bitner, Mary Jo, Servicescapes: The Impact of Physical Surroundings on Customers and Employees, " April 1992 Vol. 56, No. 2

[2] C. S. Marques and J. Ferreira, "SME innovative capacity, competitive advantage and performance in a 'traditional' industrial region of Portugal," J. Technol. Manag. Innov., vol. 4, no. 4, pp. 53-68, 2009.

[3] D. Sulistiani, "Mencapai keunggulan bersaing dengan strategi diferensiasi," EL MUHASABA J. Akunt., vol. 4, no. 2, pp. 1-17, 2014.

[4] F. Boons, C. Montalvo, J. Quist, and M. Wagner, "Sustainable innovation, business models and economic performance: An overview," Journal of Cleaner Production, vol. 45. pp. 1-8, 2013.

[5] P. F. Drucker: and D. V. to Customers, "Peter F. Drucker: delivering value to customers," Meas. Bus. Excell., vol. 6, no. 4, p. mbe.2002.26706dae.007, 2002.

[6] G. Armstrong, P. Kotler, M. Harker, and R. Brennan, Marketing: An Introduction. 2009.

[7] C. Rogers, "Carl Rogers," Inf. Theory, p. 152, 2008.

[8] S. Robbins, "Organizational Behavior," in Zhurnal Eksperimental'noi i Teoreticheskoi Fiziki, 2013, p. 676.

[9] G. G. S. Fiates, J. E. A. Fiates, F. A. R. Serra, and M. P. Ferreira, "Innovation environment in small technology-based companies,” J. Technol. Manag. Innov., vol. 5, no. 3, pp. 81-95, 2010.

[10] Lovelock, Christopher., Wirtz, Jochen., and, Mussry, Jacky." Pemasaran Jasa: Manusia, Teknologi, dan Strategi (Perspektif Indonesia)" Jilid Kedua Edisi Ketujuh. Jakarta: Erlangga, 2011

[11] K. Urabe, "Innovation and the Japanese Management System," in Innovation and Management, 1988, pp. 167-196.

[12] Musriha, "Pengaruh Servicescape dan Kualitas Komunikasi Karyawan Terhadap Loyalitas Melalui Kepuasan Nasabah Bank Mandiri di Surabaya." Jurnal issn 1411-0393. Ekuitas.Universitas Bhayangkara Surabaya. 2009.

[13] N. M. Scarborough and T. W. Zimmerer, "Effective Small Business Management," Facilities, vol. 53, no. 6 Suppl, pp. S28-31, 2011.

[14] A. S. Soegoto, "Orientasi dan Strategi Pemasaran dalam Menciptakan Keunggulan Posisional serta Dampaknya terhadap Kinerja Perguruan Tinggi,” Trikonomika, vol. 10, no. 1, pp. 19-30, 2011.

[15] Tjiptono, "Kepuasan Pelanggan,” http://digilib.unpas.ac.id, 2008. .

[16] F. Tjiptono and G. Chandra, "Tjiptono, Fandi. \&amp; Chandra, Gregory. (2004). Service, Quality dan Satisfaction. Yogyakarta; Andi.," J. Bus. Manag. Sci., vol. 4, no. 4, pp. 76-81, 2004.

[17] B. S. Dharmmesta, "Loyalitas Pelanggan: Sebuah Kajian Konseptual sebagai Panduan bagi Penalti," J. Ekon. dan Bisnis Indones., vol. 14, no. 3, pp. 73-88, 1999.

[18] P. Kotler, "Kotler on...," Manag. Decis., vol. 29, no. 2, 2011.

[19] Pankey, Tito P., Analisis Servicescape Terhadap Loyalitas Pengunjung Pada Hotel Berbintang di Manado (Studi Pada Hotel Quality Manado), Jurnal EMBA, Vol.1 no.3, 2013

[20] C. Ranaweera and J. Prabhu, "The influence of satisfaction, trust and switching barriers on customer retention in a continuous purchasing setting," Int. J. Serv. Ind. Manag., vol. 14, no. 4, pp. 374-395, 2003.

[21] Y. C. Cho, "Analyzing online customer dissatisfaction toward perishable goods," J. Bus. Res., vol. 64 , no. 11, pp. 1245-1250, 2011.

[22] John C. Mowen and M. Minor, Prilaku konsumen. 2002.

[23] G. A. Churchill and D. Iacobucci, Marketing Research: Methodological Foundations, vol. 4. Aufl. 2004.

[24] Sugiyono, Metode Penelitian Kuantitatif, Kualitatif dan R\&D. Bandung: Alfabeta, 2008. 